PENGARUH ABU TERBANG BATUBARA DAN

PUPUK KANDANG TERHADAP PRODUKTIVITAS

LAHAN BEKAS TAMBANG BATUBARA

Disertasi

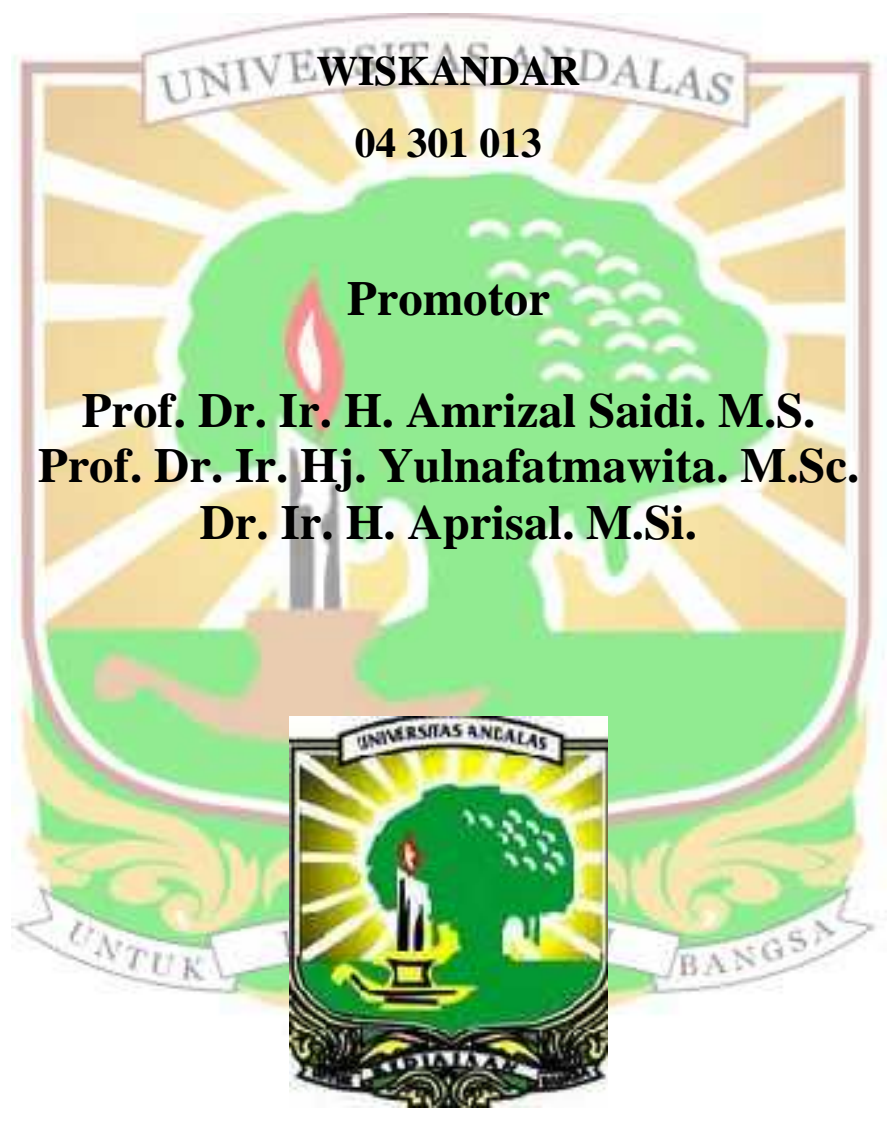

PROGRAM PASCA SARJANA

UNIVERSITAS ANDALAS

2017 


\section{PENGARUH ABU TERBANG BATUBARA DAN}

PUPUK KANDANG TERHADAP PRODUKTIVITAS

\section{LAHAN BEKAS TAMBANG BATUBARA}

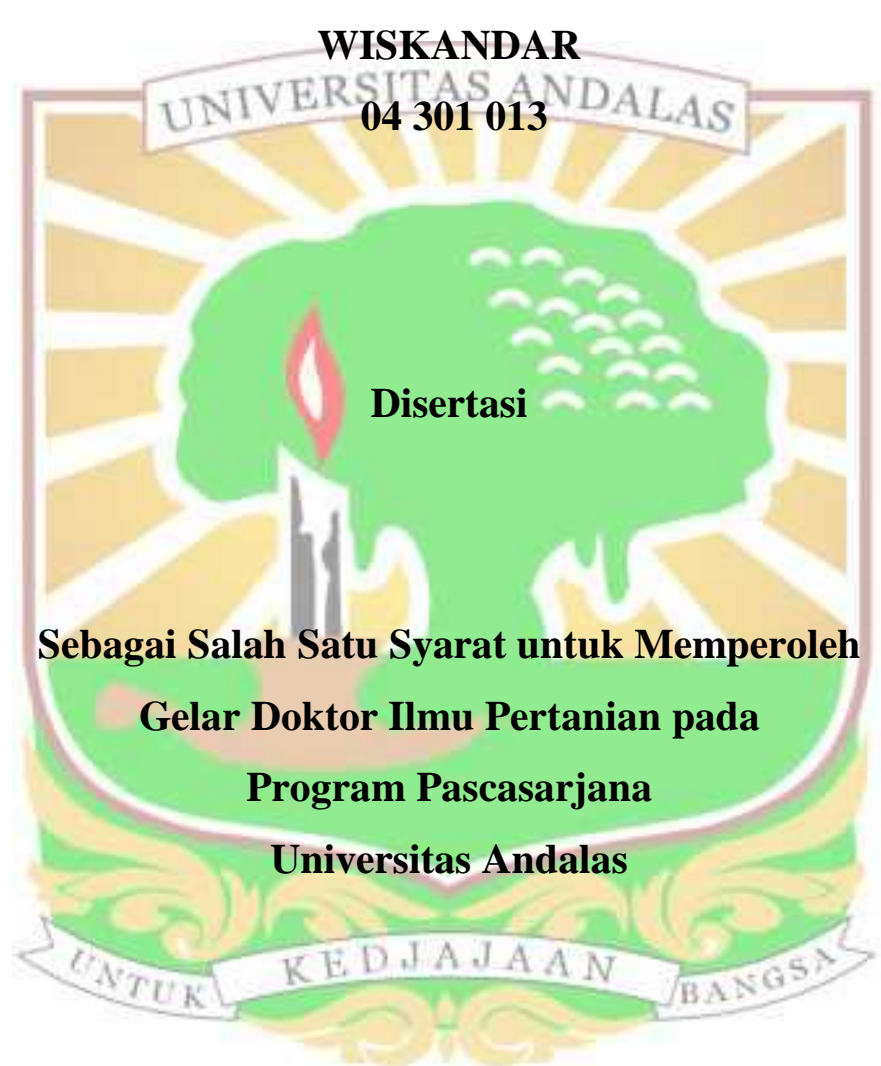

PROGRAM PASCASARJANA

UNIVERSITAS ANDALAS 
2017

\title{
PENGARUH ABU TERBANG BATUBARA DAN PUPUK KANDANG TERHADAP LAHAN BEKAS TAMBANG BATUBARA
}

\section{Oleh Wiskandar}

(Dibawah bimbingan : Prof. Dr. Ir. H. Amrizal Saidi, M.S.

Prof. Dr. Ir. Hj. Yulnafatmawita, M.Sc. dan Dr. Ir. H. Aprisal, M.Si.)

\begin{abstract}
Abstrak
Pemanfaatan abu terbang batubara (flax ash) sebagai amelioran pada tanah lahan bekas tambang batubara, selain merupakan upaya memperbaiki sifat fisik dan kimia tanah pasca tambang untuk mendukung pertumbuhan tanaman, dan juga merupakan tindakan pengendalian pencemaran lingkungan hidup oleh sisa pembakaran batubara sebagai sumber energi. Penelitian terhadap pemberian abu terbang dan pupuk kandang terhadap produktivitas tanah lahan bekas tambang batubara, pertumbuhan dan produksi jagung telah dilaksanakan pada tanah lahan bekas tambang PT. Nan Riang di Kecamatan Muara Tembesi Kabupaten Batang Hari. Tujuan penelitian ini adalah untuk mengetahui takaran terbaik dari pemberian abu terbang dan pupuk kandang terhadap sifat fisika dan kimia tanah serta pertumbuhan dan produksi jagung.

Penelitian ini dilakukan di laboratorium, rumah kaca, dan lahan bekas tambang batubara. Hasil penelitian menunjukkan bahwa interaksi pemberian abu terbang sebanyak 45 ton ha $^{-1}$ dan pupuk kandang yang berasal dari kotoran sapi sebanyak 5\% dari berat tanah adalah terbaik untuk perbaikan sifat fisika dan kimia tanah lahan bekas tambang batubara serta pertumbuhan dan produksi tanaman jagung.
\end{abstract}

Keyword: abu terbang, pupuk kandang, jagung. 


\title{
THE EFFECT OF COAL FLY ASH AND MAURE OF COW ON COAL MINE LANDS
}

\author{
by Wiskandar \\ (Supervised by : Prof. Dr. Ir. H. Amrizal Saidi, M.S. \\ Prof. Dr. Ir. Hj. Yulnafatmawita, M.Sc. dan Dr. Ir. H. Aprisal, M.Si.)
}

\begin{abstract}
Utilization of coal fly ash as ameliorant on coal mined lands, in addition to the efforts to improve the physical and chemical properties of post-mining land to support the growth of plants, and also control an environmental pollution by the combustion of coal as an energy source. Research on the effect of fly ash and manure to the soil physical and chemical properties of coal mined lands as well as the growth and production of maize has been carried out on land mined lands the Nan Riang Company in Muara Batang Hari Tembesi. The purpose of this study was to determine the dose of fly ash and manure to the soil physical and chemical properties as well as the growth and production of corn.

This research was conducted in the laboratory, greenhouse, and land after the coal mine. The results showed that the interaction fly ash as much as 45 tons ha ${ }^{-1}$ and manure from cow as much as 5\% of the weight of the soil is the best for the improvement of soil physical and chemical properties of coal mined lands as well as the growth and production of corn
\end{abstract}

Keyword: fly ash, organic matter, zea mays.

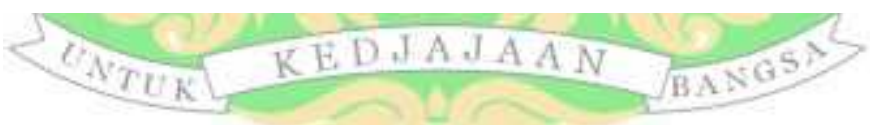

